\title{
Tip 2 Diyabetli Bireylerde Seyahat Zevk mi? Yoksa Eziyet mi? Kalitatif Bir Yaklaşım
}

\section{Is Travel Pleasure for Individuals with Type 2 Diabetes? or Torment? A Qualitative Approach}

\author{
Sibel Şentürk ${ }^{1 *}$, Nurten Terkeş ${ }^{1}$, Derya Akça $^{2}$ \\ ${ }^{1}$ Burdur Mehmet Akif Ersoy Üniversitesi, Bucak Sağlık Yüksekokulu Bucak-Burdur, Türkiye \\ ${ }^{2}$ Bursa Uludağ Üniversitesi, Sağlık Bilimleri Fakültesi, Bursa, Türkiye \\ e-mail: sibelsenturk@mehmetakif.edu.tr,nterkes@mehmetakif.edu.tr,deryaakca@uludag.edu.tr \\ ORCID: 0000-0002-5634-174X \\ ORCID: 0000- 0002-1644-8382 \\ ORCID: 0000-0001-7040-2732 \\ *Sorumlu yazar/ Corresponding Author: Sibel Şentürk \\ Gönderim Tarihi / Received: 26.03.2021 \\ Kabul Tarihi / Accepted: 05.04.2021 \\ DOI: $10.34087 /$ cbusbed.903560
}

\begin{abstract}
Öz
Giriş ve Amaç: $\mathrm{Bu}$ araştırmanın amacı, tip 2 diyabetli bireylerin seyahatleri sırasında yaşadıkları zorlukları belirlemektir.

Gereç ve Yöntemler: Tanımlayıcı ve fenomenolojik desene sahip olan bu araştırma, en az bir yıldır tip 2 diyabet tanısı almış, çalışmanın yapıldığı tarihlerde dahiliye servisinde yatmakta olan ve çalışmaya katılmayı kabul eden toplam 14 birey ile tamamlanmıştır. Veriler, araştırmacılar tarafından geliştirilen yarı yapılandırılmış form ile yüz yüze görüşme tekniği kullanılarak 35-40 dakikada toplanmıştır. Görüşmeler boyunca tip 2 diyabetli bireylerin ifadeleri ses kayıt cihazı ile kayıt altına alınmıştır. Veriler, içerik analizi yöntemi ile değerlendirilmiştir.

Bulgular: Araştırmada "seyahatin anlamı", "seyahat sırasında yaşanılan zorluklar" ve "baş etme stratejileri”" olmak üzere üç tema belirlenmiştir. Araştırmaya katılan tip 2 diyabetli bireyler seyahati, savaşa hazırlanma, zorlu bir dağa tırmanıs ve panik atak geçirmesine neden olabilecek bir kavram olarak tanımlamıșlardır. Tip 2 diyabetli bireyler seyahatleri sırasında ilaçları ve insülini muhafaza etme, şeker ölçümü ve insülin uygulama, ayak problemleri, diyet programına uyum ve hipoglisemi/hiperglisemi atakları gibi zorluklar yaşadıklarını ifade etmişlerdir. Seyahat ile ilgili problemlerle başa çıkmak için seyahat öncesi ihtiyacı olabilecek tüm malzemeleri hazır bulundurdukları, gidecekleri yeri araștırdıkları, seyahat öncesi rutin kontrollerini yaptırıp hekim ve diyabet hemşiresinden bilgi aldıklarını belirtmişlerdir.

Sonuç: Araştırma sonucunda tip 2 diyabetli bireylerin seyahat sırasında uygulanan tedavi, diyet, ayak sağlığı ve insülin regülasyonu ile ilgili sorunlar yaşadıkları tespit edilmiştir. Tip 2 diyabetli bireylerin seyahat uygulamaları sırasında hekim ve diyabet hemşireleri tarafından diyabetik bakıma yönelik detaylı bir şekilde bilgilendirilmeleri gerekmektedir.
\end{abstract}

Anahtar Kelimeler: Diyabet, Tip 2, Kalitatif çalıșma, Seyahat.

\begin{abstract}
Objective: The aim of this study is to determine the difficulties that people with type 2 diabetes experience during their travels.

Materials and Methods: This research has a descriptive and phenomenological pattern. It was completed with a total of 14 individuals who were diagnosed with type 2 diabetes for at least one year, were hospitalized in the internal medicine service at the time of the study and agreed to participate in the study. The data were collected in 35-40 minutes using the face-to-face interview technique with the semi-structured form developed by the researchers. Throughout the interviews, the expressions of individuals with type 2 diabetes were recorded with a tape recorder. The data were evaluated using the content analysis method.
\end{abstract}


Results: In the research, three themes were determined as "the meaning of travel", "difficulties experienced during travel" and "coping strategies". Individuals with type 2 diabetes who participated in the study defined travel as a concept that could cause preparing for war, climbing a difficult mountain and having a panic attack. Individuals with type 2 diabetes stated that they experienced difficulties such as preserving medications and insulin, glucose measurement and insulin administration, foot problems, compliance with diet program and hypoglycemia / hyperglycemia attacks during their travels. They stated that in order to cope with travel-related problems, they kept all the materials they might need before the travel, searched their destination, had their routine checks before the travel and received information from the doctor and diabetes nurse.

Conclusion: As a result of the research, it was determined that individuals with type 2 diabetes have problems with treatment, diet, foot health and insulin regulation while traveling. Individuals with type 2 diabetes should be informed in detail about diabetic care by their physicians and diabetes nurses during their travel practices.

Keywords: Diabetes, Type 2, Qualitative study, Travel.

\section{Giriş}

Yaşamının ayrılmaz bir parçası olan seyahat, insanların kişisel veya ticari / mesleki amaçlarla ülkelere veya olağan ortamlarının dışındaki yerlerde bulunmasına neden olan sosyal, kültürel ve ekonomik bir olgudur. Farklı amaçlarla milyonlarca insan her yıl yurt içine ve yurt dışına seyahat etmektedir $[1,2]$. 2019 yılında dünyada uluslararası seyahat edenlerin sayısı yaklaşı 1,4 milyardır ve bu sayı her geçen yıl artmaktadır. Bu seyahatlerin \%56's1 eğlence ve tatil; $\% 27$ 'si sağlık ve din; \%12'si iş amaçlıyken \%5'i spesifik olmayan seyahatlerdir [2]. Amacı ne olursa olsun yolcular seyahatleri sirasında veya sonrasında bir sağlık sorunuyla karşılaşabilmektedir. Seyahat ile ilgili hastalık riskleri; gidilecek yere, kişinin alışkanlıklarına ve altta yatan hastalıklara göre değişiklik göstermektedir. Seyahat edenlerinde seyahat sırasında meydana gelen bu değişikliklere uyum sağlaması gerekmektedir. Bu değişiklikler tüm yolcuların sağlık durumunu etkilemekle birlikte kronik hastalığı olan yolcular üzerinde daha fazla etkiye sahiptir [1,3].

Dünya çapında en yaygın görülen bulaşıcı olmayan hastalıkların başında gelen diyabet, seyahat eden bireylerde en sık görülen ikinci kronik hastalık olarak bildirilmektedir [4]. Diyabet, seyahat ettikleri yerlerde evde alıştıkları rutinleri yerine getirmekte güçlük çeken bireyler için zorlu bir durum olarak kabul edilmektedir [5]. Gün geçtikçe diyabet görülme sıklığının ve seyahat eden kişi sayısının artmasına paralel olarak diyabetli yolcu sayısı da artmaktadır [3, 6]. Bu artış ile birlikte yolculuğa her zaman yeni ve çeşitli deneyimler eşlik etmekte, özellikle uzun mesafeli yolculuklar günlük yaşamdaki değişikliklerle birlikte seyahat ile ilişkili sorunların artmasına neden olmaktadır [7,8].

Diyabet, büyük ölçüde kişinin kendisi tarafından yönetilen bir hastalık olmasına rağmen diyabetliler seyahat sirasında diyet ve fiziksel aktivite ile ilgili rutinlerinde değişiklikler, insülin dozunu ayarlamadaki zorluklar ve bulaşıcı hastalık riski dahil olmak üzere glisemik kontrollerini etkileyebilecek birçok problem yaşayabilmektedir [1, 7, 9-11]. Hızlı trans-meridyen hava yolculuğu, standartların altında yiyecek ve su kalitesi, aşırı sıcaklar ve alışılmadık doğa ortamlarının tümü, özellikle insülin tedavisine bağımlı olan diyabetlilerde metabolik acil durumlar ve zayıf glisemik kontrol riskini artırmaktadır [5]. İnsülin kullanan diyabetlilerin sürekli yaşayabilecekleri zorluklar arasında; yolculuk sırasında diyabet malzemelerinin bagajlara dağıtımı, bagaj kaybı, farklı saat dilimine geçiş, dehidratasyon, havayolu yemek seçenekleri, havaalanı güvenliğinden geçiş, rakım, iklim ve insülin saklama koşulları yer almaktadır [12]. Araba ile seyahat eden diyabetlilerde insülin doğrudan güneş 1şı̆̆ına maruz kalabilir ve beklenmedik hipoglisemiler ile glisemik denge bozulabilir [7, 13]. Ayrıca diyabetlilerin seyahat yeri seçiminin diyabet tanısından ve insülin kullanımından etkilenebileceği ve bu hastaların bir kısmının seyahatten tamamen kaçınabildiği bildirilmektedir [1, 9].

Seyahat sırasında optimum diyabet yönetimini sürdürmek zor olabilmektedir. Günlük rutinler değişebilmekte ve düzensiz olabilmektedir. $\mathrm{Bu}$ da diyabetin yönetimi üzerinde büyük bir etkiye sahiptir [14]. Diyabetliler için güvenli ve sağlıklı seyahat, fiziksel aktivite seviyesi, beslenme ve risk ile ilgili rutinlerde meydana gelen değişiklikler nedeniyle özellikle zorlayıcı olabilecek koşullar altında glikoz seviyelerini yönetmeyi gerektirmektedir [15]. Diyabette seyahatin önlenmesi çözüm olmamakla birlikte diyabetliler tıpkı diğer kişiler gibi keyifli bir seyahat deneyimi yaşayabilmeleri için daha fazla dikkat ve bakıma ihtiyaç duymaktadır [7]. Dikkate alınması gereken çok şey var gibi görünse de iyi bir planlama ile optimal diyabet yönetimi sürdürülebilmektedir. Diyabet hemşirelerinin uygun diyabet yönetimini sürdürmeye çalışırken seyahat etmenin potansiyel tehlikeleri hakkında seyahat edecek olan diyabet hastalarına tavsiyelerde bulunmaları önemlidir [14]. Tüm diyabet hastaları için genel tavsiyeler benzer olmakla birlikte, her hastanın fizik ve sağlık düzeyine göre özel gözlemlere ihtiyacı vardır [7]. Böylelikle diyabetli bireyler yeterli hazırlık ve kendi kendine yönetim becerileriyle güvenli bir şekilde seyahat edebilir [9, 11].

Literatürde diyabetli bireylerin seyahatleri sırasında insülin uygulama ve saklama, diyet programına uyum, hipoglisemi/hiperglisemi atakları yaşama ve ayak problemlerine ilişkin yaşadıkları zorluklarla ilgili kantitatif çalışmalar bulunmakla birlikte kalitatif yapılmış olan bir çalışmaya rastlanmamıştır 
$[1,3-5,8,10,12,14]$. Bu nedenle tip 2 diyabetli bireylerin seyahatleri sırasındaki yaşadıkları sorunlara ilişkin derinlemesine deneyimlerin incelenmesi, bu süreçte gerçek ihtiyaçların belirlenmesi ve bu ihtiyaçlara yönelik bakım hizmetlerinin planlanması açısından önemlidir.

$\mathrm{Bu}$ araștırma, tip 2 diyabetli bireylerin seyahatleri sırasında yaşadıkları zorlukları belirlemek amacıyla yapılmıştır.

\section{Materyal ve Metot}

2.1.Araştırmanın Tipi: Araştırma, betimsel veri analizine dayalı niteliksel bir araştırma olarak planlanmıştır.

2.2.Araştırmanın Evren ve Örneklemi: Bu araştırmanın evrenini Ekim-Aralık 2019 tarihleri arasında Bucak Devlet Hastanesi'nin dahiliye polikliniğine muayene olmaya gelip yatış kararı verilen tip 2 diyabetli bireyler oluşturmuştur. Niteliksel araştırmalarda örneklem sayısı ile ilgili herhangi bir kural belirlenmemiştir. Araştırmanın örneklemine alınan katılımcıların sorulara verdikleri cevaplar birbirine benzer olmaya başlayınca doyum noktasına ulaşıldığ 1 ifade edilmekte ve veri toplama işlemi sonlandırılmaktadır [16]. Örneklemi (a) en az bir yıldır tip 2 diyabet tanısı almış, (b) çalıșmanın yapıldığg tarihlerde dahiliye kliniğinde yatarak tedavi gören, (c) 40 yaş ve üzeri, (d) iletişim ve algılama sorunu olmayan (e) Türkçe anlayabilen ve konuşabilen ve (f) çalışmaya katılmayı kabul eden toplam 14 tip 2 diyabetli birey oluşturmuştur.

2.3.Veri Toplama Formu: $\mathrm{Bu}$ çalışmada veriler, araştırmacılar tarafından literatür taranarak hazırlanan tip 2 diyabetli bireylerin özelliklerini irdeleyen yarı yapılandırılmış görüşme formu ile toplanmıştır [3, 4, 6-9, 11-15]. Görüşme formunun ilk bölümü tip 2 diyabetli bireylerle ilgili 8 sorudan (yaş, cinsiyet, medeni durum, eğitim durumu, mesleği, hastalık yılı, eşlik eden hastalıklar, tedavi şekli) oluşmaktadır. Diğer bölümde ise tip 2 diyabetli bireylerin seyahatleri sırasında zorluk yaşayıp yaşamadıklarını belirlemek için yönlendirici olmayan, geneli kapsayan 3 adet açık uçlu soru yöneltilmiştir. Çalışmada tip 2 diyabetli bireylere yöneltilen açık uçlu sorular, 'Tip 2 diyabetli bir insanın seyahati nasıl olur? Tanımlar mısınız', 'Tip 2 diyabetli bir insan olarak seyahatiniz sırasında Tip 2 diyabet bakımı ile ilgili yaşadığınız zorluklar var mı? Nası1?' ve 'Seyahatiniz sırasında yaşadığınız zorluklarla baş edebilmek için neler yapıyorsunuz? Nasıl? Neden?' şeklinde sıralanmıştır. Veri toplama formunun anlaşılırlığı açısından nitel araştırma alanında uzman bir akademisyenden sorular hakkında görüş alınmış ve anket formuna son hali verilmiştir. 2.4. Verilerin Toplanması: Veriler, yüz yüze görüşme yöntemi kullanılarak yarı yapılandırılmış soru formu aracılığıyla derinlemesine bireysel görüşme yapılarak toplanmıştır. Görüşmeler, Ekim-Aralık 2019 tarihleri arasında, tip 2 diyabetli bireylerin klinikte olduğu ve tedavi programina herhangi bir nedenle engel olmayacağ1 saatlerde yapılmıştır. Görüşmelerin sağlıklı bir şekilde yürütülmesi için görüşmeyi yapan araştırmacıya tahsis edilen odada görüşmeler ortalama 35-40 dakika arasında gerçekleştirilmiştir. Görüşme sırasında tip 2 diyabetli bireylerin ifadeleri ses kayıt cihazı ile kaydedilmiş ve gerekli yerlerde notlar alınmıștır.

2.5.Etik İzin: Araştırmanın yapılabilmesi için Mehmet Akif Ersoy Üniversitesi Girişimsel Olmayan Klinik Araştırmalar Etik kurulundan 07.11.2018 toplant tarihli ve GO 2018/111 karar no ile etik kurul izni, tip 2 diyabetli bireylerden de sözlü ve yazılı onam alınmış, ses kayıt cihazının kullanılacağı hakkında bilgilendirme yapılmış ve ses kaydının gizliliği konusunda da güvence verilmiștir. $\mathrm{Bu}$ çalışma, Dünya Tıp Birliği (WMA) Helsinki Bildirgesi İyi Klinik Uygulamaları gözetilerek yapılmıştır.

2.6.Verilerin Analizi: Araştırmanın veri analizi, betimleme, analiz ve yorumlama olmak üzere üç aşamada gerçekleştirilmiştir. Yapılan tüm görüşmelerin ses kayıtları ve tip 2 diyabetli bireylerin yazılı olarak vermiş olduğu beyanlar manuel olarak deşifre edilmiştir. Veriler NVivo8 programı kullanılarak kodlanmıştır. Yapılan kodlamalar sınıflandırılarak tip 2 diyabetli bireyler için seyahatin anlamı, seyahat sırasında yaşanılan zorluklar ve baş etme stratejileri olmak üzere 3 tema belirlenmiştir. Çalışmada Tip 2 diyabetli bireylerin görüşmelerinin kağıda aktarılmıs şeklini okumaları ve doğruluğunu onaylamaları sağlanmıștır. Bu şekilde katılımcı teyidi sağlanarak çalışmanın iç geçerliliği ve güvenilirliği sağlanmıştır. Ayrıca, kâğıda aktarılmış olan verilerle ilgili yapılmış olan çözümlemeler (kodlar ve kodların temalara atanması) için nitel araştırma alanında tecrübe sahibi olan iki akademisyenden kodlamalar ile ilgili görüş alınmıştır. Bu şekilde meslektaş yardımı olarak ifade edilen güvenilirlik çalışması da yerine getirilmiştir [17].

\section{Bulgular ve Tartışma \\ 3.1.Bulgular}

Araştırmaya katılan tip 2 diyabetli bireylerin yaş ortalamas1 56,8 (Min:43-Max:69), \%64,2'si ilköğretim mezunu, \%85,7'si evli, \%57,1'i 1-5 y1l arasında tip 2 diyabet hastası olduğunu, \%78,5'i eşlik eden bir veya daha fazla hastalığının olduğunu ve tedavi şeklinin insülin olduğunu belirtmiştir (Tablo 1).

Tip 2 diyabetli bireylerle yapılan bireysel görüşmeler sonucunda "seyahatin anlamı", "seyahat strasinda yaşanilan zorluklar" ve "baş etme stratejileri" olmak üzere 3 tema ve 6 alt tema belirlenmiștir. Görüşmelerden elde edilen tema ve alt temalar Tablo 2'de verilmiştir.

\section{Tema 1: Seyahatin Anlamı}

Araştırmaya katılan tip 2 diyabetli bireylerin bir kısmı seyahatin anlamını ölüm korkusu ile eşleştirdikleri, bazıları seyahatin savaşa hazırlanma, zorlu bir dağa tırmanma, özürlü gibi hissetme ve panik atağ1 
tetikleyen bir kavram olarak nitelendirdikleri tespit edilmiştir. Yapılan açıklamalardan bazıları aşağıdaki gibidir:

- Diyabetli bir insan için seyahat, savaşa hazırlanma gibidir. Çünkü ortaya çıkabilecek tüm sorunlara yönelik ilaçlarınızı, insülinlerinizi, şeker ölçüm cihazınızı, buz akülerini, raporlarınızı, yiyeceklerinizi, yedek kıyafetlerinizi yani her şeyinizi yanınıza ekstra bir çanta olarak almanız gerekiyor (D1, K, 69 yaşında).

- Seyahat, gözümde tırmanılması zor bir dağ gibi benim için. Yolculuk sırasında başıma ne geleceğini bilmediğim için seyahatimin ne zaman biteceğini bilmemek beni endişelendirir (D3, E, 55 yaşında).
- Seyahat, çıkmadan önce 10 kere düşündüğüm, dikkat etmemem durumunda ölümle sonuçlanabilecek bir durum olarak algıladığım için panik atak yaşıyormuşum hissi oluşturan ve çoğunlukla vazgeçtiğim bir deneyimdir (D10, E, 54 yaşında).

Tema 2: Seyahat Sırasında Yaşanılan Zorluklar

Seyahat sırasında yaşanılan zorluklar teması 4 alt tema altında incelenmiştir. Bunlar, "şeker ölçümü, insülin uygulama ve muhafaza etme", "ayak problemleri", “diyet programina uyum" ve "hipoglisemi/hiperglisemi atakları" dır.

Tablo 1: Tip 2 diyabetli bireylerin demografik özellikleri

\begin{tabular}{|c|c|c|c|c|c|c|c|}
\hline Kod & Yaş & Cinsiyet & $\begin{array}{l}\text { Eğitim } \\
\text { Durumu }\end{array}$ & $\begin{array}{l}\text { Medeni } \\
\text { durumu }\end{array}$ & $\begin{array}{l}\text { Hastalık } \\
\text { Yılı }\end{array}$ & $\begin{array}{ll}\text { Eşlik } & \text { Eden } \\
\text { Hastalık } & \end{array}$ & $\begin{array}{l}\text { Tedavi } \\
\text { Şekli }\end{array}$ \\
\hline 1 & 49 & $\bar{E}$ & Lise & Evli & $1-5 \mathrm{y} 1 \mathrm{l}$ & - & İnsülin \\
\hline 2 & 69 & $\mathrm{~K}$ & Lise & Evli & $11-15$ y1l & HT & $\begin{array}{l}\text { Oral } \\
\text { antidiyabetik }\end{array}$ \\
\hline 3 & 55 & $\mathrm{E}$ & İlköğretim & Evli & $1-5 \mathrm{y} 1 \mathrm{l}$ & Pankreas CA & İnsülin \\
\hline 4 & 50 & $\mathrm{E}$ & İlköğretim & Evli & $11-15$ y1l & KOAH & Sadece diyet \\
\hline 5 & 52 & $\mathrm{~K}$ & Okur-yazar & Evli & $5-10 y 11$ & - & İnsülin \\
\hline 6 & 67 & $\mathrm{~K}$ & İlköğretim & Bekar & $1-5$ y1l & KBY & İnsülin \\
\hline 7 & 43 & $\mathrm{E}$ & Fakülte & Evli & $1-5 \mathrm{y} 1 \mathrm{l}$ & Anemi & İnsülin \\
\hline 8 & 62 & $\mathrm{E}$ & İlköğretim & Evli & $5-10$ y1l & KBY & İnsülin \\
\hline 9 & 58 & $\mathrm{~K}$ & İlköğretim & Evli & $1-5 \mathrm{yil}$ & Meme CA & İnsülin \\
\hline 10 & 54 & $\mathrm{E}$ & İlköğretim & Evli & 1-5 yil & Pankreas CA & İnsülin \\
\hline 11 & 60 & $\mathrm{~K}$ & İlköğretim & Evli & $1-5 \mathrm{y} 1 \mathrm{l}$ & HT & İnsülin \\
\hline 12 & 48 & $\mathrm{~K}$ & İlköğretim & Bekar & $1-5 \mathrm{y} 1 \mathrm{l}$ & - & $\begin{array}{l}\text { Oral } \\
\text { antidiyabetik }\end{array}$ \\
\hline 13 & 66 & $\mathrm{E}$ & Okur-yazar & Evli & 5-10 y1l & HT & İnsülin \\
\hline 14 & 63 & $\mathrm{~K}$ & İlköğretim & Evli & $11-15$ y1l & HT & İnsülin \\
\hline
\end{tabular}

Tablo 2: Görüşmelerden elde edilen tema ve alt temalar

\begin{tabular}{|c|c|c|c|}
\hline Kategori & Temalar & & Alt Temalar \\
\hline \multirow{3}{*}{ Seyahat Deneyimi } & Seyahatin Anlamı & & \\
\hline & $\begin{array}{l}\text { Seyahat Sirasında } \\
\text { Zorluklar }\end{array}$ & Yaşanılan & $\begin{array}{l}\text { - } \quad \text { Şeker ölçümü, insülin uygulama ve } \\
\text { muhafaza etme } \\
\text { - } \quad \text { Ayak problemleri } \\
\text { - } \quad \text { Diyet programına uyum } \\
\text { - } \quad \text { Hipoglisemi/hiperglisemi atakları }\end{array}$ \\
\hline & Baş etme Stratejileri & & $\begin{array}{ll}\text { - } & \text { Hazırlıklı olma-Araştırma } \\
\text { - } & \text { Kontrole gitme-Eğitim alma }\end{array}$ \\
\hline
\end{tabular}

Tema 2.1. Şeker ölçümü, insülin uygulama ve muhafaza etme

Araştırmaya katılan tip 2 diyabetli bireylerin tamamı seyahatleri sırasında şeker ölçümü ve insülin uygulaması yaparken insanların rahatsız edici ya da acıyan gözlerle baktığını, insanların bakışlarından rahatsız oldukları için insülin uygulaması yaparken o alanı kapatmaya çalıştıkları, insülinleri muhafaza ederken buz akülerini soğutuculara koymaların istediklerinde muavinler tarafindan bazen azarlanır tarzda durumlara maruz kaldıklarını ifade etmişlerdir. Yapılan açıklamalardan bazıları aşağıdaki gibidir:

Seyahat sırasında şeker ölçümü ya da insülin uygulaması yaparken insanların sanki bulaşıcı hastalığ 1 varmış gibi davranmaları ya da üzülen gözlerle bakmaları beni rahatsız ediyor (D5, K, 52 yaşında).

İnsülin uygulaması sırasında başka kişilerin gözleri üzerimde olduğu için göbekten yapmıyorum. Sürekli kollarıma yapmak zorunda kalıyorum (D11, K, 60 yaşında) 
- Bir keresinde muavinden yedek buz aküsünü soğutucuya koymasını istediğimde soğutucunun dolu olduğunu ve koyamayacağını belirtiğini hiç unutmam (D8, E, 62 yaşında)

Tema 2.2. Ayak Problemleri

Araştırmaya katılan tip 2 diyabetli bireylerin bir kısmı uzun seyahatler sonrasında ayaklarının şiştiğini, ayakkabı giymekte zorlandıklarını, yanma ve karıncalanma oluştuğunu, geceleri uyurken ayaklarını sürekli karınlarına doğru çekmek zorunda kaldıklarını, ayak ağrıları nedeniyle uyuyamadıklarını, seyahat sonrasında da bu problemlerin belli bir süre devam ettiğini belirtmişlerdir. Yapılan açıklamalardan bazıları aşağıdaki gibidir:

- Seyahatte en fazla ayaklarım şişiyor. Bir keresinde ayaklarım iki katına çıkmıştı neredeyse. Sürekli masaj yaptık, şişlik inmeyince acile gitmek zorunda kalmıştık. Ayağım şiş olunca benim yüzümden evdekilerde gezmeye gidememişti (D14, K, 63 yaşında).

- Ayaklarımda seyahat süresince çok fazla yanma ve karıncalanma meydana geliyor. Ayaklarımı nereye koyacağımı bilemiyorum (D2, K, 69 yaşında; D8, E, 62 yaşında).Tema 2.3. Diyet Programına Uyum

Araştırmaya katılan tip 2 diyabetli bireylerin büyük çoğunluğu seyahat sırasında diyete uyum sağlamakta zorlandıklarını, yemek saatlerini kaçırdıkları için ana ve ara öğünlerin birbirine karıştığını, öğün atladıklarını ya da atıştırmalıklarla geçiştirdiklerini, yanlarında yemek taşıdıklarında ise seyahat sırasında otobüste yemek yerken diğer yolcuların rahatsız olduklarını ve muavinlerin uyarıda bulunduklarını belirtmişlerdir. Yapılan açıklamalardan bazıları aşağıdaki gibidir:

- Seyahat sirasında yediklerime maalesef dikkat edemiyorum. Onun için sürekli yanımda bir şeyler taşımak zorunda kalıyorum (D7, E, 43 yaşında).

- Seyahat sirasinda diyetime uymakta zorlaniyorum. Uzun yolculuklarda ana ve ara öğünler birbirine karışıyor ve en az bir hafta toparlanmakta zorluk çekiyorum (D9, K, 58 yaşında).

Tema 2.4. Hipoglisemi/Hiperglisemi Ataklar

Araştırmaya katılan tip 2 diyabetli bireylerin büyük çoğunluğu yolculuk süresinin uzamasının stresini artırdığını ve şekerinin yükseldiğini, uykusuzluk, yorgunluk, düzensiz beslenme gibi durumlarda da hipoglisemi atakları yaşadıklarını ifade etmişlerdir. Yapılan açıklamalardan bazıları aşağıdaki gibidir: Seyahat sırasında yolculuğun gereksiz yere uzaması stres nedeniyle şekerimin yükselmesine neden oluyor (D13, E, 66 yaşında).

- Yolculuk sırasında yanıma yiyecek bir şeyler almayı unuttuğumda hipoglisemi atağı yaşıyorum. Hemen yanımdakilerden ya da muavinden şeker istiyorum. $\mathrm{Bu}$ ataklar dengemi mahvediyor, elimden-ayağımdan güç kuvvet kesiliyor, ölü gibi oluyorum (D6, K, 67 yaşıında).

Tema 3: Baş etme Stratejileri

Seyahat sırasında yaşanılan zorluklarla baş etme stratejileri teması 2 alt tema altında incelenmiştir.
Bunlar, "hazırlıklı olma-araştırma" ve "kontrole gitmeeğitim alma" dır.

\section{Tema 3.1. Hazırlıklı Olma-Araștırma}

Araştırmaya katılan tip 2 diyabetli bireylerin tamamı seyahat öncesi gerekli olan tüm malzemeleri bir gün öncesinden hazırlayıp stres düzeylerini azalttıklarını ve eksik malzeme götürme durumunu yaşamadıklarını, gidecekleri yerlerde en yakın hastanenin nerede olduğunu ve hava durumunu araştırdıklarını, duruma göre yanlarına yedek kıyafet, yiyecek, yastık ve tabure aldıklarını, insülin uygularken göbeğine yapacaksa üzerine bir örtü örttüğünü, ferahlamak için yanında kolonya bulundurduğunu, aşırı terleme durumları için vücudunu ve yüzünü silmek için bez bulundurduğunu, kusma nedeniyle hipoglisemi atağı yaşamamak için bulantıyı önleyici ilaç aldığını, bir kısmı da yanlarına diyabet kartını aldıklarını ve yanında seyahat ettikleri kişilere diyabet hastası olduklarını söylediklerini belirtmişlerdir.

- Seyahat öncesi tüm eşyaları eksik olmaması için bir gün öncesinden hazırlayıp defalarca kontrol ediyorum. İlaçlarımı, insülin kalemimi ve şeker ölçüm cihazımı mutlaka yanıma alıyorum (D10, E, 54 yaşında; D5, K, 52 yaşında).

- Ayaklarımın şişmemesi için dar ayakkabı kesinlikle giymiyorum. Bazen ayaklarımın sallanmaması için tabure kullanıyorum (D2,K, 69 yaşında).

- Eğer tek başıma seyahat edeceksem yanıma oturan kişiye şeker hastası olduğumu, şekerim düştüğünde bana şeker vermesini tembihliyorum (D3, E, 55 yaşında).

Tema 3.2. Kontrole Gitme-Eğitim Alma

Araştırmaya katılan tip 2 diyabetli bireylerin bir kısmı seyahatten bir hafta önce hastaneye kontrole gittiğini, rutin olarak tüm tahlillerini yaptırıp seyahate çıkmaya bir engelinin olup olmadığını hekimiyle konuştuğunu, hekimin önerisi doğrultusunda hareket ettiğini, hekimi ve diyabet hemşiresi ile görüşerek seyahat sırasında dikkat edilmesi gerekenler hakkında bilgi aldığını belirtmişlerdir.

- Seyahatten en az bir hafta önce hekimim ile görüşüp rutin kontrollerimi yaptırırım (D7, E, 43 yaşında)

- Şehir dişına seyahat edeceksem diyabet hemşiremle mutlaka görüşüp neler yapmam gerektiği konusunda bilgi alırım, kendisinin telefonu da olduğu için acil bir durumla karşılaştığımda hemen kendisiyle irtibat kurarım (D9, K, 58 yaşında).

\subsection{Tartışma}

Diyabetli bireylerde seyahat deneyimi, hastalığın seyri ve gelişebilecek komplikasyonlar, uygulanan tedavi, diyet programı, gidilecek yerin mesafesi, hava durumu, ulaşım aracının tipi gibi çeşitli nedenlerden dolayı birçok zorlukla karşı karşıya kalmalarına neden olmaktadır [1, 5, 7, 9-13]. Bu bağlamda çalışmamızda tip 2 diyabetli bireylerin seyahatleri sirasında yaşadıkları zorluklar "seyahatin anlamı", "seyahat sırasında yaşanılan zorluklar" ve "baş etme stratejileri" olmak üzere üç ana temayla ortaya konmuştur. 


\section{Tema 1. Seyahatin Anlamı}

Seyahate her zaman yeni ve çeşitli deneyimler eşlik etmektedir. Özellikle uzun mesafeli yolculuklar kişilerin günlük yaşamında değişikliklere sebep olur. Ortaya çıkan yeni koşullar stresli olabilir ve olumsuz sonuçlar doğurabilir [7]. Diyabet gibi kronik hastalığı olan kişiler seyahat ederken birçok zorlukla karşılaşmaktadır [10]. Diyabet, seyahat etmeyi engellemez sadece daha fazla dikkat gerektirir. Diyabetliler seyahatlerini planlarken temin etmeleri gereken araçları, yapmaları gereken düzenlemeleri ve istenmeyen durumlara karşı almaları gereken her türlü önlemi göz önünde bulundurmalıdır. Bu planlama, hastalar için büyük bir öneme sahiptir [7]. Bu çalışmada tip 2 diyabetli bireylerin çoğunluğu seyahatin anlamını ölüm korkusu ile eşleştirdikleri, bazıları seyahatin savaşa hazırlanma, zorlu bir dağa tırmanma, özürlü gibi hissetme ve panik atağ1 tetikleyen bir kavram olarak nitelendirdikleri tespit edilmiştir. Diyabetlilerin bu düşüncelerinin değişen koşullar ile nasıl başa çıkacağını bilmeme, seyahatleri sırasında insülin dozlarını ayarlamada ve kan glikoz düzeyini dengede tutmada zorluklar yaşayabilme olasılıklarından kaynaklandığ 1 düşünülebilir.

Tema 2. Seyahat Sırasında Yaşanılan Zorluklar

Seyahat sırasında diyabetli bir yolcu için meydana gelebilecek olası zorluklar arasında değişken öğün saatindeki gecikmeler, diyet ve alışılmadık yiyeceklerden kaynaklanan zayıf glisemi kontrolü, insülin taşımak ve saklamak, iklim ve yaşam koşulları değişiklikleri, fiziksel eforun artması veya azalması ve stres yer alır $[7,9,18]$. Bu çalışmada seyahat sırasında yaşanılan zorluklar, "şeker ölçümü, insülin uygulama ve muhafaza etme", "ayak problemleri", "diyet programına uyum" ve "hipoglisemi/hiperglisemi atakları" olarak belirlenmiştir.

Seyahat eden diyabetliler insülin uygulamak, taşımak ve muhafaza etmek, glisemi kontrolünü sağlamak için şeker ölçümü yapmak gibi ek yüklerle karşı karşıyadır [5]. Pinsker ve ark.'nın 503 tip 1 diyabetli hasta ile yaptıkları bir çalışmada sürekli subkutan insülin infüzyonu kullanan diyabetlilerin birincil kaygıları malzemelerikaybetmek iken, kullanmayanların dengesiz kan glikoz düzeyi (hipoglisemi ve hiperglisemi) ile ilgili endişeleri olduğu bildirilmiştir [19]. Levy ve ark. yaptıkları retrospektif bir çalışmada, seyahat sirasında tip 1 diyabet hastalarının yalnızca \% 38'inin şeker takibini arttırdığı ifade edilmiştir [15]. Elkins ve ark. yaptıkları bir çalışmada seyahat sırasında diyabet yönetimi hakkında danışmanlık arayan diyabetliler, insülin dozu ve kan şekeri izleme ile ilgili endişelerinin olduğunu bildirmişlerdir [18]. Bu çalışmada tip 2 diyabetli bireylerin tamamı seyahatleri sırasında şeker ölçümü ve insülin uygulaması yaparken insanların rahatsız edici ya da acıyan gözlerle baktığını ve insülinleri muhafaza etmekte zorlandıklarını ifade etmişlerdir. $\mathrm{Bu}$ ifadelerin toplumun diyabet hakkında farkındalığının gelişmemiş olması, insülin uygulamasının diyabetli hastalar için önemli olduğu konusunda bilinçsiz olmalarından kaynaklandığı düşünülebilir.

Diyabetlilerde ayak değerlendirmesi ve ayak bakımının güçlendirilmesi oldukça önemlidir [10]. İskemik veya nöropatik ülserler, selülit veya osteomiyelit gibi komplikasyonların gelişmesini önlemek için diyabetliler için iyi bir ayak bakımı şarttır. Diyabetlilere seyahat sirasında kendi kendine ayak bakımı uygulamaları yapmaları ve alt ekstremite enfeksiyonu veya yaralanmasinın erken belirtilerini tespit etmeleri için ayaklarını kontrol etmeleri tavsiye edilebilir [5]. Diyabetlilere kaç gün seyahat edecekleri ve katılmayı planladıkları aktiviteler sorulmalı, ardından sıkmayan uygun ayakkabılar önerilmelidir. Seyahatte yeni ayakkabılar giyilecekse, bu ayakkabılar yolculuktan 2 ila 3 hafta önce satın alınmalı ve kullanılmalıdır. Uygun olmayan ayakkabılar, sıkan çoraplar ve hareketsizlik ayaklarda ödeme sebep olabilir [6]. Bu araştırmada tip 2 diyabetli bireylerin bir kısmı uzun seyahatler sonrasında ayaklarının şiştiğini, ayakkabı giymekte zorlandıklarını, yanma ve karıncalanma oluştuğunu, geceleri uyurken ayaklarını sürekli karınlarına doğru çekmek zorunda kaldıklarını, ayak ağrıları nedeniyle uyuyamadıklarını, seyahat sonrasında da bu problemlerin belli bir süre devam ettiğini belirtmişlerdir. Diyabetlinin uçağa, trene, arabaya veya otobüse binmeden önce birkaç dakika yürümesi ve seyahat sırasında oturduğu koltuğun rahat olması önemlidir. Kan dolaşımına yardımcı olması ve ödemi önlemek için seyahat ettiği araçta otururken ayak bileklerini ve parmaklarını bükmeleri ve ayaklarını esnetmeleri tavsiye edilebilir [7]. Diyabet hastalarında nöropatiye bağlı hasar riskinin daha yüksek olması nedeniyle, ayak bakımı konusunda sürekli dikkatli olmaları önerilmelidir [6, 14].

Glikoz ihtiyacı seyahat sırasında değişebilir. Özellikle uzun mesafeli seyahatler glisemik kontrolü etkileyebilecek şekilde değişen yemek saatlerine, sınırlı ve farklı yemek seçeneklerine, sınırlı fiziksel aktiviteye ve strese yol açabilir. Diyabetlilerin seyahat ederken hipoglisemiden kaçınmaları için öğün atlamamaları ve önceki yeme düzenlerini sürdürmeleri önemlidir [10, 18]. Seyahatte her şey normal rutinimizden farklı olabilir. Farklı yiyecekler yemenin yanı sira yeme miktarı artabilir [14]. Lin ve ark.'nın çalışmasında diyabetlilerin \%36,7'sinin seyahatte yiyecek alımını arttırdığı bildirilmiştir [3]. Seyahat sırasında beslenme alışkanlığı devam ettirilmeye çalışılmalı, yeni yiyecekler mümkün olduğu kadar düşük miktarlarda denenmelidir [13]. Diyabetliler için yemek seçenekleri seyahat sırasında sinırlı olabilir, bu nedenle önceden planlama yapmak önemlidir. Kara ve deniz yolculuğu tipik olarak yemek seçimlerinde daha fazla esneklik sunduğundan, bu daha çok hava yolculuğu sirasında geçerlidir [20]. Lin ve ark. 139 tip 2 diyabetli ile yaptıkları bir çalışmada diyabetlilerin yalnızca \%3,6'sının uçağa binmeden önce diyabetik yemek rezervasyonu yaptırdığını bildirmişlerdir [3].

$\mathrm{Bu}$ araştırmada tip 2 diyabetli bireylerin büyük çoğunluğu seyahat sırasında diyete uyum sağlamakta 
zorlandıklarını, yemek saatlerini kaçırdıkları için ana ve ara öğünlerin birbirine karıştığını, öğün atladıklarını ya da atıştırmalıklarla geçiştirdiklerini belirtmişlerdir. Seyahatleri sirasında yiyeceklerini yanlarında taşıdıklarında ise otobüste yemek yerken diğer yolcuların rahatsız olduklarını ve muavinlerin uyarıda bulunduklarını belirtmişlerdir. Seyahat etmek her zaman plan doğrultusunda gitmeyebilir. Trafikte kalınabilir veya seyahat edilecek araç gecikme yapabilir. Hipoglisemik olayları önlemeye veya tedavi etmeye yardımcı olmak için sağlıklı atıştırmalıklar, kolayca ulaşılabilen bir el çantasında taşınmalıdır [6, 7 , 20]. Seyahat sırasında el çantasında taşınan yiyeceklerin yoğun bir kokuya sahip olan baharatlı, sarımsaklı ya da yerken fazla ses çıkaran yiyeceklerden oluşmaması çevredeki insanların rahatsız olmasını engelleyebileceği için önerilebilir. Yolculuk sırasında araçta görevli kişilere durum ile ilgili bilgi verilmesinin diyabetlilerin imkânlara daha kolay ulaşabilmelerini ve yiyeceklerini tüketirken daha rahat olmalarını sağlayacağı düşünülebilir.

Diyabette, seyahat sırasında düzensiz kan glikozu önemli bir sorundur. Diyabetli hipoglisemiyi tahmin etme ve bununla başa çıkma gibi ek yüklerle karş1 karşıyadır [5]. Seyahatte beslenme, aktivite ve stres düzeyinin değişmesi gibi önemli değişikliklerle birlikte kan glikoz düzeyini kontrol etmek kolay olmayabilir $[15,21,22]$. Lin ve ark. 'nın yapmış oldukları çalışmada, 134 tip 2 diyabetli birey değerlendirilmiş ve $\%$ 8,6'sının seyahat sırasında hipoglisemi yaşadığ bildirilmiştir [3]. Levy ve ark. yaptıkları retrospektif bir çalışmada, seyahat sırasında tip 1 diyabet hastalarının \%11'inin glisemik durumunun kötüleştiğini bulmuşlardır [15]. Pinsker ve ark. yaptıkları bir çalışmada hastaların \%74'ünün seyahat ederken daha fazla hipoglisemi ve/veya hiperglisemi yaşadığını bildirilmişlerdir. Diyabetlilerin \%9'unun diyabet nedeniyle uluslararası seyahatlerden kaçındığ belirtilmektedir [19].

$\mathrm{Bu}$ araştırmada tip 2 diyabetli bireylerin hipoglisemi/hiperglisemi atakları yaşadıkları belirlenmiştir. Hipogliseminin ve hipergliseminin önlenmesi, erken tanınması ve yönetimi hakkında vurgu yapmak önemlidir. Diyabetli yolculara, her zaman karbonhidrat içeren atıştırmalıkların yanı sıra glikoz tabletleri, jelleri veya sıvıları taşımaları konusunda öneride bulunulmalıdır. Kas içi glukagon kitleri, insülin kullananlarda, özellikle hipoglisemi riski yüksek olanlarda çok faydalıdır [10]. Hiperglisemiye yol açmamak için hipoglisemi durumu dişında, mümkün olduğunca meyve suyu gibi kan şekerini hızla yükseltebilecek içecekler içmekten kaçınması önerilmelidir [7].

Tema 3: Baş Etme Stratejileri

Seyahat öncesi hazırlı, planlamayı ve hepsinden önemlisi de güvenlik hususlarının her zaman dikkate alınmasını gerektirmektedir [21]. Diyabetli kişiler seyahatten önce sağlığını sürdürmeye hazırlanmalı ve diyabeti yönetmek için donanımlı olmalıdır. Diyabetlilerin kan glikoz düzeyini regüle etmek amacıyla nasıl seyahat edeceklerini, temin etmeleri gereken araçları, gerçekleştirmeleri gereken eylemleri ve almaları gereken tedbirleri dikkatlice organize etmeleri gerekir [7]. Çalışmamızda tip 2 diyabetli bireylerde seyahatten bir gün öncesi gerekli olan tüm malzemeleri hazırladıklarını ve gidilecek yerle ilgili araştırma yaptıklarını belirtmişlerdir. Pinsker ve ark. diyabetliler ile yaptıkları çalışmada ise seyahatin en zorlu kısmının yolculuk hazırlığı olduğunu belirtmişlerdir [19]. Önceden planlama, sorunları ve acil durumları en aza indirmede önemli bir rol oynayabilir $[14,18]$. Seyahat etmek, stresli olabilirken stres kan şekerini yükseltebilir. Gidilecek yer hakkında bilgi toplamak ve seyahatin tümünü planlamak stresi azaltabilir [7]. Seyahat sirasında diyabetliler durumları hakkında yolculuk yaptığı kişileri, otel personelini ve rehberleri bilgilendirmelidir. Böylelikle ilgili kişiler hipoglisemi gibi durumlara yardımcı olmak için daha donanımlı olacaktır [6].

Diyabetliler için genel seyahat tavsiyeleri glikoz düzeyindeki dalgalanmaları en aza indirmek ve seyahatle ilgili diğer riskleri azaltmak için seyahatten önce yeterli hazırlık, uygun malzemelerin temini, komplikasyonlara karşı uyanık olma, diyet ve ilaçlar hakkında danışmanlığı içerir $[8,22]$. Genel öneri seyahatten en az 4-6 hafta önce sağlık uzmanlarını görmeleri yönündedir [18, 23]. Çalışmamızda tip 2 diyabetli bireylerde seyahat öncesi kontrollere gittiğini, hekim ve diyabet hemşiresinden eğitim aldıklarını belirtmişlerdir. Lin ve ark.'nın yaptıkları bir çalışmada seyahat planı olan tip 2 diyabetlilerin yalnızca $\% 21,6$ 'sının birinci basamak sağlık hizmetlerine başvurup seyahat planlamasını anlattığı ve seyahat öncesi danışmanlık istediği bildirilmiştir [3]. Flatherty ve ark. yaptıkları bir çalışmada tip 1 diyabetlilerin seyahat sırasında hipoglisemiden kaçınma ile ilgili konularda farkındalığının yüksek olduğunu fakat seyahat öncesi danışmanlık alma olasılıklarının daha düşük olabileceğini açığa çıkarmışlardır [5]. Elkins ve ark.'nın yaptıkları bir çalışmada hastaların \% 69'unun seyahatten önce herhangi bir danışmanlık aramadığ belirtilmiştir [16]. Bu bağlamda seyahat öncesi kontrole gitme ve eğitim almanın diyabetliler arasında yaygınlaştırmanın önemli olduğu düşünülmektedir.

\section{Araştırmanın Sinırlılıkları}

Çalışma, nitel araştırma tekniği ile yapılması nedeniyle elde edilen bulgular sadece araştırmaya katılan 14 tip 2 diyabetli birey görüşü ile sinırlı olup, genellenemez. Ayrıca, küçük hasta sayılarıyla yapılan nitel çalışmalar, bulguların genel popülasyona aktarılmasında önemli önyargılara ve zorluklara tabidir; ancak, literatürde diyabetli bireylerin seyahatleri sırasında yaşadıkları zorlukları ifade eden nitel bir çalışmanın bulunmaması ileride yapılacak olan çalışmalar için güçlü tavsiyelerde bulunmaktadır.

\section{Sonuç}

Araştırma sonucunda tip 2 diyabetli bireylerin seyahati zevkten ziyade bir eziyet olarak tanımladıkları, seyahat 
sırasında uygulanan tedavi, diyet, ayak sağlığı ve insülin regülasyonu ile ilgili sorunlar yaşadıkları tespit edilmiştir. $\mathrm{Bu}$ sorunlarla baş etmek için ihtiyacı olabilecek tüm malzemeleri hazır bulundurdukları, gidecekleri yeri araştırdıkları, seyahat öncesi rutin kontrollerini yaptırıp hekim ve hemşiresinden bilgi aldıkları tespit edilmiștir. Diyabetli hastaların seyahatleri sırasında bu zorluklarla karşılaşmaması amaciyla diyabette seyahat konusunun diyabet eğitimi içerisinde yer alması, seyahat öncesi sağlık taramalarının rutin olarak yaptırılmasının gerekliliğinin vurgulanmas1, toplumun diyabet konusunda farkındalığının geliştirilmesi ve diyabetlilerin seyahat hazırlığını bir kontrol listesi doğrultusunda yapmaları önerilebilir.

\section{Referanslar}

1. Alduraibi, R, Almigbal, T, Alrasheed, A, Batais, M.A, Knowledge, attitudes, and practices of primary health care physicians regarding the pre-travel counselling of patients with type 2 diabetes in Riyadh, Saudi Arabia, BMC Family Practice, 2020, 21(1), 1-9.

2.The World Tourism Organization (UNWTO). Global and regional tourism performance (2020) https://www.unwto.org/global-and-regional-tourism-performance. (accessed 22.02.2021)

3. Lin, I.W, Chang, H.H, Lee, Y.H, Wu, Y.C, Lu, C.W, Huang, K.C, Blood sugar control among type 2 diabetic patients who travel abroad: A cross sectional study, Medicine, 2019, 98(13), 1-4.

4. Gagneux-Brunon, A, Andrillat, C, Fouilloux, P, Daoud, F, Defontaine, C, Charles, R, Lucht, F, Botelho-Nevers, E, Pre-travel advice seeking from GPs by travellers with chronic illness seen at a travel clinic, Journal of Travel Medicine, 2016, 23(3), 1-5.

5. Flatherty GT, Leong SW, Finn Y, Sulaiman LH, Noone C. Travellers with type 1 diabetes: questionnaire development and descriptive analysis of knowledge and practices. Journal of Travel Medicine, 2020, 27(6), 1-28.

6. Mullin, R, Kruger, D, Young, C.F, Shubrook, J.H, Navigating travel with diabetes, Cleveland Clinic Journal of Medicine, 2018 85(7), 537-542.

7. Morteza, I, Mahboobeh Sadat, H, Hossein, P, Travel guidance for people with diabetes, International Journal of Travel Medicine and Global Health, 2015, 3(4), 149-154

8. Pavela, J, Suresh, R, Blue, R.S, Mathers, C.H, Belalcazar, L.M, Management of diabetes during air travel: A systematic literature review of current recommendations and their supporting evidence, Endocrine Practice, 2018, 24(2), 205-219.

9. Ghosh, S, Bajaj, S, Chatterjee, P, Agarwal, S, Aravind, S.R, Chawla, R, et al., Diabetes and travel, International Journal of Diabetes in Developing Countries, 2018, 38, 4-10.

10. Priya, G, Kalra, S, Dutta, D, Grewal, E, Maisnam, I, Aggarwal, S, Up in the air with diabetes: A systematic review of literature and a pragmatic approach to diabetes management during long-distance travel, Journal of Diabetes \& Metabolic Disorders, 2020, 7(31), 110.

11. Şentürk, S, Bıçak, D, Akça, D, Diyabet ve seyahat, Arşiv Kaynak Tarama Dergisi, 2018, 27(4), 426-439.

12. Charlton, A.R, Charlton, J.R, World travel with type 1 diabetes using continuous subcutaneous insulin infusion, British Journal of Diabetes, 2019, 19(2), 141-146.

13. Örük, G, Diyabet ve seyahat. In: İlkova H, Kaya A (eds). Türk diyabet yılllı̆̆ $2016-2017,2017,77-83$.

14. Costa, SDa, Diabetes management during trips abroad: Planning ahead to reduce the risks, Journal of Diabetes Nursing, 2014, 18 260-265.

15. Levy-Shraga, Y, Hamiel, U, Yaron, M, Pinhas-Hamiel, O. Health risks of young adult travelers with type 1 diabetes, Journal of Travel Medicine, 2014, 21(6), 391-396.

16. Jolley J. Hemşirelik ve Sağlık profesyonelleri için araştırma ve kanıta dayalı uygulamaya giriş. Nobel Yayıncılık, Ankara, 2014.
17. Başale, $\mathrm{H}$, Determination of validity, reliability and sample size in qualitative studies, Dokuz Eylul University E-Journal of Nursing Faculty, 2016, 9(1), 23-28.

18. Elkins, B.E, True, M.W, Ramos, R.G, Cranston, M.M, How do you get there with diabetes? Results a survey of diabetic travelers, Journal of Tourism Hospital, 2017, 3(2), 1-7.

19. Pinsker, J.E, Schoenberg, B.E, Garey, C, Runion, A, Larez, A, Kerr, $\mathrm{D}$, Perspectives on long-distance air travel with type 1 diabetes, Diabetes Technology \& Therapeutics, 2017, 19(12), 744-748.

20. Nassar, A.A, Cook, C.B, Edelman, S, Diabetes management during travel, Diabetes Management, 2012, 2(3), 205-212.

21. Macneill, G, Fredericks, C, Vacation ease: Travelling with an insulin pump, Canadian Journal of Diabetes, 2015, 39(3), 178-182.

22. Patel, N.R, Kennedy, A, Blickem, C, Reeves, D, Chew-Graham, C, I'm managing my diabetes between two worlds: beliefs and experiences of diabetes management in British South Asians on holiday in the east - A qualitative study, Journal of Diabetes Research, 2016, 1-8.

23. Trikudanathan, S, Hirsch, I.B, Diabetes management "up in the air": It's time for consensus, Endocrine Practice, 2018, 24(6), 599-601.

http://edergi.cbu.edu.tr/ojs/index.php/cbusbed isimli yazarın CBU-SBED başlıklı eseri bu Creative Commons Alıntı-Gayriticari4.0 Uluslararası Lisansı ile lisanslanmıştır.

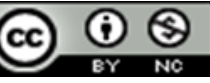

